\title{
Readiness to Administer First Aid to Casualties of Fire Disasters in Secondary Schools in Kilimanjaro Region, Tanzania
}

\author{
Emmanuel Jeremiah Kileo $^{1}$, Gadi Koda ${ }^{2}$, Ogoti E. Okendo ${ }^{3}$ \\ ${ }^{1} \mathrm{PhD}$ Candidate in Education \\ ${ }^{2,3}$ Member of Faculty of Education
}

Affiliation:

Mwenge Catholic University, Tanzania

\begin{abstract}
This study was conducted to determine how secondary schools in Kilimanjaro region in Tanzania were prepared to administer first aid to casualties of fire disasters. This study was guided by the Protection Motivation Theory (1975) and employed a convergent research design under mixed methods research approach. The study sample was obtained through stratification. The study revealed among other things, that most schools had first aid kit facilities, offered guidance and counselling services and respondents were confident enough to administer first aid. The study concluded that secondary schools had to a great extent prepared to administer first aid to casualties of fire disasters, if such menaces occurred in schools. The
\end{abstract}

study recommended inter alia, for more training on first aid in secondary schools.

Key Words: First Aid, Preparedness, Fire Disaster

\section{Introduction}

Students spend most of their time in schools and are vulnerable to injuries and mild ailments, hence requiring first-aid care (Qureshi, 2018). Every school therefore has legal responsibility to take care of each and every member of the school (Santhikrishna \& Rekha, 2018). In other words, responsibility for children shifts from parental guardians to school personnel who then have an ethical responsibility to carefully consider the safety needs of students while under their supervision (Stough \& Lee, 2018). Subsequently, school leaders become increasingly responsible for a new primary responsibility of creating safer schools for students concurrently with a secondary mission of developing and helping them to realize their cognitive goals (Barton, 2009). This is because students are among the most vulnerable population group when natural or man-made hazards strike (Nderitu \& Muthwii, 2015). Families and communities expect schools to keep children and youths safe from threats; whether human-caused emergencies like crime and violence or natural hazards like disease outbreaks and accidents (REMS Technical Assistance Center, 2014). Similarly, Santhikrishna and Rekha (2018) point out that safety of students is prime concern of teachers, parents and community. To put this into perspective, parents might more likely forgive school leaders if test scores go down, but they will be much less forgiving if something happens to their children that could have been prevented or been managed (Trump, 2011).

First aid is the temporary and immediate treatment given to a person who is injured or suddenly becomes ill with the facilities or materials available at that time before regular medical help is imparted (Santhikrishna \& Rekha, 2018). When disasters like fire occur in schools, first aid is crucial in bringing immediate relief and reducing or avoiding altogether fatalities among victims of such menaces. In the school context, it is important that school leaders ensure there exists an ability to quickly locate injured victims, provide them with the first aid required to stabilize their conditions, and rush them to a facility where they can receive the medical assistance necessary to save their lives (Coppola, 2015). 
The prevalence of fire disasters in schools compromises the state of school fire safety. Apparently, studies show that injuries, emotional suffering and death are among devastating consequences of school fire disasters. For instance, according to Campbell (2019), the local fire departments in the United States responded to an estimated average of 3,320 fires in school properties from pre-school through grade twelve in 2013-2017. The fires on the school properties caused an estimated average of one civilian death, 42 civilian injuries, and 42 million dollars in direct property damage a year. Furthermore, an alleged arson attack on a St. Bernard secondary school boys' dormitory in Rakai, southern Uganda, left at least 10 people dead and dozens more injured. In this incident, officials said that dormitory doors were padlocked, trapping dozens inside (BBC News, 2018). In Tanzania, three form one students were killed when fire broke out at Ilala Islamic secondary school in Dar es Salaam, torching a dormitory in a second floor (Kiango, 2020; Felix \& Shani, 2020). In Kilimanjaro region, among other fire incidents that occurred in the year 2021, a fire disaster occurred in Sangiti secondary school where 180 students survived an inferno after four girls' dormitories were gutted by fire (Global Publishers, 2021). Although, fire disasters are associated with injuries, psychological trauma and death to mostly students, little is known about how secondary schools are prepared to administer first aid to casualties particularly of fire disasters.

\section{Statement of the Problem}

Schools' readiness to administer first aid to casualties of fire disasters is an essential component of school fire safety. While students in particular, are susceptible to experiencing trauma, injuries and death associated with incidents of fire disasters at school, first aid is key in reducing suffering or pain experienced by victims of fire disasters. Similarly, first aid has the potential of reducing or eliminating the possibility of death occurring among victims of fire disasters. Several studies have been conducted on first aid in secondary schools. Examples of these studies include Calandrim et al. (2017) and Reveruzzi et al. (2020). Nonetheless, there is scant empirical evidence on the state of preparedness of schools in administering first aid to casualties of fire disasters, if such incidents occur in these institutions. The present study therefore sought to determine how secondary schools in Kilimanjaro region were prepared to administer first aid to casualties particularly of fire disasters, if such menaces occurred at school.

\section{Theoretical Framework}

Protection Motivation Theory (PMT) propounded by Rogers (1975) was employed to guide this study. The theory was originally developed to help comprehend fear appeals and how people cope with them. In other words, Protection Motivation Theory concerns how people process threats and select responses to cope with the danger brought about by those threats. The theory consists of two stages. The first, threat appraisal, relates to the perceived risk of the threat. Threat appraisal is composed of two elements: perceived vulnerability which refers to the likelihood of the threat to occur; and perceived severity which refers to how bad the effects of the threat will be. Second, copping appraisal, is made up of three elements: response efficacy which refers to how effective the response will be; self-efficacy which refers to how able people are to respond to the threat; and response cost which refers to how costly the response will be (Oakley et al., 2020).

In this study, Protection Motivation Theory was employed because it describes how school stakeholders, particularly school leaders might react in a protective way against perceived threats of injuries, trauma, or death associated with fire disasters. The presumption is, for school leaders like heads of schools to enhance secondary schools' readiness to administer first aid, they first appraise the threat of fire disasters by considering the likelihood of such incidents occurring (vulnerability) and their associated consequences (severity) such as destruction, injuries, psychological trauma or death to students and staff. Then after, they appraise the coping mechanisms at their disposal to curb the threat where in the case of this study they might consider how effective administration of first aid will be in reducing suffering or fatalities among victims of fire disasters at school (response-efficacy), how able they are to administer first aid (self-efficacy), and the cost to be incurred in enhancing administration of first aid (response cost) such as purchasing first aid kits at school. As a rule of thumb, if the school leaders' copping appraisal outweighs their threat appraisal, they will more likely enhance schools' readiness to administer first aid to casualties of fire disasters, thus 
reducing or eliminating risk of students and staff being injured, trauma or experiencing fatalities, if incidents of fire disasters occur at school.

\section{Review of Related Literature}

A study conducted in Nigeria by Raji and Akanbi (2019) on emergency risk management factors and effectiveness of public senior secondary schools in the Federal Capital Territory (FCT) revealed that the majority of respondents opined that students' counselling services (SCS) were available and adequate. These findings attested that the studied schools had fairly prepared to administer psychological first aid. The study employed descriptive survey research design where the population comprised of all principals (57) and teachers $(4,014)$ in the 57 public senior secondary schools. The current study however, linked counseling services particularly to readiness of secondary schools to administer psychological first aid to students and staff after experiencing trauma or shock, if a fire disaster occurs. Furthermore, this present sought to determine if schools had teachers or other personnel designated to offer counselling services to students or other staff members.

A research conducted in Kenya by Mutua (2016) on school based factors influencing fire safety preparedness in public secondary schools in Lower Yatta Sub-County, Kenya revealed inadequacy of first aid kits. For example, majority of teachers indicated that first aid supplies were inadequate. Similarly, through observation, first aid supplies were found to be inadequate in most of schools. In addition, when principals were asked on when first aid supplies were supplied, majority of these respondents confirmed that these supplies were provided. The findings generally, suggested that the studied schools had not prepared enough to administer first aid. The study employed a descriptive survey design, and targeted 26 public secondary schools, 26 principals, 115 secondary school teachers and 6,320 students. The study collected data using questionnaires and observation schedule. The data was subjected to descriptive statistics. Moreover, qualitative data generated from the questions was organized into themes, patterns and categories pertinent to the study and then-after, presented thematically in line with the study objectives. The present study however, sought to inquire if first aid kits in schools have medical facilities as a way of secondary schools in Kilimanjaro region get ready to administer first aid to casualties of a fire disaster.

In contrast to Mutua's (2016) findings that revealed inadequacy of first aid supplies, the findings of a descriptive survey in Eldoret West District, Uasin Gishu County, Kenya by Ruttoh (2019) revealed that the majority of respondents agreed to the statement 'first aid education and facilities were available in schools'. Ruttoh (2019) study employed a descriptive survey design. The study was conducted in 80 public and private secondary schools within Eldoret West District (18 boarding and 62 day schools). A proportionate sample was used to select 4 boarding secondary schools and 12 day secondary schools. Questionnaire and interview methods were used to collect data which was analyzed though descriptive and inferential statistics for quantitative data and thematic analysis for qualitative data. The two studies however unveiled mixed opinions between the researchers, a situation that calls for more research on the matter. This present study therefore sought to determine if schools had first aid kits equipped with medical facilities.

Another descriptive research was conducted by Ayonga (2016) to investigate fire emergency preparedness in Nairobi public secondary schools, Kenya. The study revealed that in most of the schools, the number of people who could administer first aid in case of a fire emergency were less than 5. However, in one of the schools, 159 respondents could do first aid as a result of being trained by the St. Johns' Community. Generally, the findings indicated inadequate level of preparedness in administering first aid. The study employed a descriptive survey design whereby its target population was all 118 public secondary schools in Nairobi County. Furthermore, stratified random sampling technique was used to select 2 schools from each of the 17 constituencies (strata) thus, obtaining a sample of 34 public secondary schools. Subsequently, questionnaire and interview methods were used to collect data from 34 head teachers who were the only participants for the study. The study also collected data through observation method, and through textual and visual analysis. The collected data was then analyzed through inferential statistics. While the study revealed that only few respondents could administer first aid, the current study sought to inquire if training on first aid is conducted in secondary schools. 
Again in Kenya, a study by Simatwa and Odera (2018) was conducted to determine the contribution of teacher attitude to management of student safety in emergency incidents in public secondary schools. Regarding teacher attitude on rescue activities in the provision of students' safety in emergency incidents, the study findings revealed that out of 270 teachers and 32 principals, the overall mean rating for their confidence to administer first aid to casualties was 3.33 which was interpreted as moderate. Even so, their desire to assist those in immediate danger, management of irrational behavior and rescue activities had overall mean ratings at 3.79, 3.61 and 3.58 respectively where all were interpreted as high. These findings suggested that although most of the teachers and principals were fairly confident to administer first aid to casualties, they had high desire to assist those in immediate danger, ready to manage irrational behavior and ready to perform rescue activities. The present study aimed at not only inquiring from respondents about confidence to administer first aid but also willingness to provide such assistance.

The reviewed empirical studies presented findings related to readiness of secondary schools to administer first aid to casualties as an important component of fire disaster preparedness. These studies unveiled that most secondary schools had no adequate number of first aid kits and few people who could perform first aid. Furthermore, these studies showed that teachers and principals were confident enough to administer first aid. Nevertheless, students' willingness and confidence to administer first aid had not been established in these studies. Although commended for these findings, there is little empirical evidence on other variables associated with readiness to administer first aid in secondary schools which inter alia, include inquiring about availability of reliable vehicles to rush the sick/injured at school to hospitals, linking school neighboring community relationship with first aid, and linking students' - teachers' social ties with administration of first aid to casualties. In addition, while first aid is meant to be administered to both physically injured and psychologically inflicted victims, most studies had put less attention to how secondary schools were prepared to assist victims affected psychologically by fire disasters, if such incidents occur in schools. Subsequently, the present study addressed these overlooked variables to fill the gap.

\section{Research Methodology}

This study employed mixed methods research approach. More specifically, the study employed the convergent design where data were collected from District Fire Officers, District Education Officers, heads of schools, teachers and students. This study obtained its sample through stratification. Schools were stratified into two where a stratum of 21 public secondary schools and a stratum 14 private secondary schools were obtained. From each of the selected schools, 4 teachers and 6 students were sampled through stratification based on gender ( 2 male teachers and 2 female teachers; 3 male students and 3 female students). The sample sizes of teachers and students were therefore 140 and 210 respectively. Nonetheless, 7 District Education Officers, 4 District Fire Officers and 35 heads of schools were involved in this study based on virtue of their positions. This study employed questionnaire, interview, and observation methods of data collection. In order to ensure validity of instruments, consultation with experts in the field of Educational Planning and Administration was made by the researcher in order to improve the research instruments. Similarly, feedback from the respondents in the pilot study was significant in improving the instruments thus, ensuring their validity. The reliability of questionnaires was determined by using the Statistical Package for Social Sciences (SPSS) software to compute the Cronbach's Alpha coefficient for each questionnaire. The reliability of qualitative instruments was ensured by the researcher focusing on employing methodological strategies that ensured credibility (trustworthiness), transferability, dependability and confirmability of the findings. Furthermore, the reliability of interview guides was ensured through verbatim transcription of information gathered from the interviewees.

\section{Presentation and Discussion of Findings}

Table 1 summarizes the heads of schools', teachers' and students' responses on readiness of secondary schools to administer first aid to casualties of a fire disasters, if they occur at school.

\section{Table 1}

Responses on Readiness of Secondary Schools to Administer First Aid to Casualties of a Fire Disaster 


\begin{tabular}{|c|c|c|c|c|c|c|c|c|c|c|c|}
\hline \multirow{2}{*}{ Statement } & \multirow[t]{2}{*}{ Respondents } & \multicolumn{2}{|l|}{ SD } & \multicolumn{2}{|l|}{ D } & \multicolumn{2}{|l|}{$\mathrm{U}$} & \multicolumn{2}{|l|}{ A } & \multicolumn{2}{|l|}{ SA } \\
\hline & & $\mathrm{f}$ & $\%$ & $\mathrm{f}$ & $\%$ & $\mathrm{f}$ & $\%$ & $\mathrm{f}$ & $\%$ & $\mathrm{~F}$ & $\%$ \\
\hline & HOSs & & & & & & & & & 35 & 100 \\
\hline \multirow{4}{*}{ School offers counseling services } & Teachers & 17 & 12.3 & 29 & 21.0 & 21 & 15.2 & 33 & 23.9 & 38 & 27.5 \\
\hline & HOSs & & & & & & & 18 & 51.4 & 17 & 48.6 \\
\hline & Teachers & & & & & 18 & 13.0 & 21 & 15.2 & 99 & 71.7 \\
\hline & Stuc & 22 & 10.6 & 17 & 8.2 & 62 & 30 & 43 & 20.8 & 63 & 30.4 \\
\hline \multirow{3}{*}{$\begin{array}{l}\text { School has a designated teacher for } \\
\text { guidance and counselling }\end{array}$} & $\mathrm{HO}$ & & & & & & & 13 & 37.1 & 22 & 62.9 \\
\hline & Teac & & & & & & & 18 & 13.2 & 118 & 86.8 \\
\hline & Stu & & & 13 & 6.3 & 64 & 30.8 & 65 & 31.3 & 66 & 31.7 \\
\hline \multirow{3}{*}{$\begin{array}{l}\text { There is a reliable vehicle around at school } \\
\text { to rush the injured/sick to a nearest } \\
\text { hospital }\end{array}$} & $\mathrm{HO}$ & & & & & 2 & 5.7 & 5 & 14.3 & 28 & 80 \\
\hline & Tea & 5 & 3.6 & 17 & 12.3 & 30 & 21.7 & 29 & 21.0 & 57 & 41.3 \\
\hline & Stud & 23 & 11.2 & 41 & 19.9 & 40 & 19.4 & 44 & 21.4 & 58 & 28.2 \\
\hline \multirow{3}{*}{$\begin{array}{l}\text { Social ties are fostered among students and } \\
\text { staff members }\end{array}$} & HOSs & 3 & 8.6 & 5 & 14.3 & 8 & 22.9 & 5 & 14.3 & 14 & 40.0 \\
\hline & Teac & & & & & & & 10 & 7.3 & 127 & 92.7 \\
\hline & Students & 6 & 2.9 & 20 & 9.6 & 37 & 17.8 & 63 & 30.3 & 82 & 39.4 \\
\hline \multirow{2}{*}{$\begin{array}{l}\text { Positive relationship is fostered between } \\
\text { school \& community }\end{array}$} & HOSs & & & & & & & & & 34 & 100 \\
\hline & Teachers & & & 2 & 1.4 & 15 & 10.9 & 31 & 22.5 & 90 & 65.2 \\
\hline \multirow{3}{*}{$\begin{array}{l}\text { You are confident to administer first aid to } \\
\text { casualties of a fire disaster }\end{array}$} & HOSs & & & & & & & 3 & 8.6 & 32 & 91.4 \\
\hline & Teachers & 17 & 12.3 & 33 & 23.9 & 33 & 23.9 & 18 & 13.0 & 37 & 26.8 \\
\hline & Students & 46 & 22.1 & 32 & 15.4 & 23 & 11.1 & 31 & 14.9 & 76 & 36.5 \\
\hline \multirow{3}{*}{$\begin{array}{l}\text { You are willing to administer first aid to } \\
\text { casualties of a fire disaster }\end{array}$} & HOSs & & & & & & & & & 35 & 100 \\
\hline & Teachers & & & & & 4 & 2.9 & 63 & 46.0 & 70 & 51.1 \\
\hline & Students & & & 4 & 1.9 & 60 & 28.8 & 45 & 21.6 & 99 & 47.6 \\
\hline \multirow[t]{3}{*}{ School receives training related to first aid } & HOSs & 24 & 68.6 & 8 & 22.9 & 2 & 5.7 & 1 & 2.9 & & \\
\hline & Teachers & 48 & 35.0 & 56 & 40.9 & 24 & 17.5 & 9 & 6.6 & & \\
\hline & Students & 117 & 56.8 & 31 & 15.0 & 27 & 13.1 & 15 & 7.3 & 16 & 7.8 \\
\hline \multirow{3}{*}{$\begin{array}{l}\text { Student prefects are involved in overseeing } \\
\text { the well-being of other students }\end{array}$} & HOSs & & & & & 1 & 2.9 & 3 & 8.6 & 31 & 88.6 \\
\hline & Teachers & 16 & 11.8 & 10 & 7.4 & 20 & 14.7 & 49 & 36.0 & 41 & 30.1 \\
\hline & Students & 22 & 10.6 & 17 & 8.2 & 62 & 30 & 43 & 20.8 & 63 & 30.4 \\
\hline
\end{tabular}

Source: Field data (2021).

Note: $\mathrm{SD}$ - Strongly Disagree

$$
\begin{aligned}
& \text { D - Disagree } \\
& \text { U - Undecided } \\
& \text { A - Agree } \\
& \text { SA - Strongly Agree }
\end{aligned}
$$

Table 1 shows that while all heads of schools (100\%) agreed that first aid kit facilities were available at school, only slight majority of teachers (51.4\%) agreed. These findings implied that although, heads of schools indicated to a very great extent that their schools had first aid kit facilities, teachers only opined that these first aid kit facilities were available at a fairly moderate extent. These findings suggested that there were mixed opinions among heads of schools and teachers. Nonetheless, information obtained from all District Education Officers through interviews revealed that efforts are made by the government to enhance health safety at schools and that a portion of governmental grant that schools receive is allocated for purchasing medical facilities like first aid kits to enhance health safety at school. In relation to Protection Motivation Theory (1975), the provision of funds to schools in form of grants with a portion of such fund allocated for purchasing medical facilities implies enhanced schools' ability to cope with the threat of fire disasters by covering response costs in administration of first aid to casualties of fire disasters in schools, if such menaces occur. Such initiatives taken by the government are significant as they are intended to ensure the safety of students and staff in secondary schools. Apparently, the provision of governmental grants to schools allocated for purchasing medical facilities under fees free basic education is in line with the 2015 Education and Training Policy which ascertains on the government's commitment to enhance safety in schools and Teachers' colleges. Similarly, through observation, the researcher noted that while most of the surveyed schools $(91.4 \%)$ had first aid kits with several equipment like pair of scissors, cotton wool, 
bandages, and methylated spirit, 3 schools had first aid boxes with no medical facilities at all in them. These findings implied that, although the government provides grants for procurement of medical facilities, some schools might be misallocating such fund for other purposes. Nevertheless, the presence of first aid kits (boxes) in all surveyed schools suggest that most schools could administer first aid to casualties who might have experienced injuries or burns if a fire disaster occurs in secondary schools.

With regards to whether secondary schools offer counseling services, all heads of schools (100\%), majority of teachers (86.9\%), and slight majority of students (51.2\%) expressed affirmative opinions by agreeing on the matter. The findings suggested that counseling services were offered in secondary schools which is a likely indicator that if a fire disaster occurred, students and staff who might experience psychological trauma might also be counselled not to experience more emotional suffering. These finding concur with a Raji and Akanbi (2019) study conducted in Nigeria which revealed that the majority of respondents (59.7\%) opined that students counseling services were available and adequate at school. Similarly, a qualitative study conducted by Amuli (2020) revealed that heads of schools are instructed by Regional Education Officers and District Education Officers to help casualties of a fire disaster with first aid before they are sent to health centers or dispensaries or hospitals to receive further treatment.

Furthermore, pertaining to whether schools had designated personnel or teacher(s) for guidance and counseling, all heads of schools (100\%), all teachers (100\%) and the majority of students $(63.0 \%)$ expressed affirmative opinions by agreeing. The findings implied that considering the fact that fire disasters can cause psychological trauma to school community members especially among students, having teachers or personnel assigned with the responsibility of offering guidance and counseling in secondary schools indicates that these institutions were prepared to administer psychological first aid to casualties of fire disasters if they occurred.

In order to determine if victims of a fire disaster could be rushed to nearest health care facilities, it was crucial to inquire if schools had reliable vehicles around which could be used for such purpose. The findings showed that the majority of heads of schools $(94.3 \%)$ and teachers $(62.3 \%)$ expressed affirmative opinions by agreeing. Similarly, when interviewed, all District Education Officers pointed out that only a few public secondary schools owned reliable vehicles as compared to the private schools which own more reliable vehicles. In addition, the District Education Officers commented that most public secondary schools relied much on teachers' private vehicles to take students in students' health emergency situations. Nevertheless, these interviewees pointed out that it was fortunate that most secondary schools in Kilimanjaro region were located near health care facilities like dispensaries and hospitals. These findings implied that despite of most public schools in particular having unreliable vehicles to rush the victims of a fire disaster to nearby hospitals, if such menaces occurs, there are health centers near these schools.

Social ties among students and teachers are crucial for school community members to help each other especially when experiencing adversities like fire disasters. It was therefore important for this study to inquire on the matter. The findings showed that slight majority of heads of schools $(54.3 \%)$, all teachers $(100 \%)$, and the majority of students $(69.7 \%)$ expressed affirmative opinions by agreeing that social ties between teachers and students were fostered at school. Similarly, information obtained through interviews with the District and Education Officers revealed that secondary schools strengthen social ties among students and staff for instance, through extra-curricular activities like debates, sports, games, and clubs. Nonetheless, these District Education Officers pointed out that sometimes after students are punished because of their misbehavior at school, they express hatred to teachers but generally, social ties are to a very great extent fostered among students and staff in secondary schools. These findings implied that if a fire disasters occurred, the school community members could help each other by assisting the victims through administration of first aid.

Again, the positive relationship between schools and their neighboring community members is paramount for each side to extend help to the other in case of adversities like fire disasters. Apparently, obtaining information on the matter was also significant in indicating the likelihood that neighboring school community members would extend help to a school that has experienced a fire disaster. While all heads of 
schools $(100 \%)$ and teachers $(87.7 \%)$ expressed affirmative opinions by agreeing that positive relationship was fostered between the school and neighboring community members, only few teachers $(1.4 \%)$ disagreed. These findings concur with the information gathered through interviews with the District Education Officers who also revealed that positive relationship was fostered between secondary schools and their neighboring community members by schools engaging school community members in activities like construction of school buildings. Additionally, the fact that most schools enroll students from around their neighboring communities strengthened positive relationship between the schools and their nearby community members. These findings implied that based on the positive relationship that exists between secondary schools and their neighboring community members, it was expected that schools could receive assistance from the neighboring community members which might include first aid to casualties of a fire disaster, if such an incident occurs.

Pertaining to confidence to administer first aid to casualties of a fire disasters, all heads of schools (100\%) and majority of students $(51.45 \%)$ expressed affirmative opinions by agreeing while only 39.8 percent (\%) of teachers agreed. While the findings implied that heads of schools were confident enough to administer first aid, these findings coincide with the study findings by Simatwa and Odera (2018) who revealed that principals responded with an overall mean rating of 3.33 which was interpreted as being adequate. The findings implied that the respondents were confident enough to administer first aid to casualties of a fire disaster. These findings further suggested a state of readiness among heads of schools, teachers and students in responding to a fire disaster. Furthermore, regarding to the willingness to administer first aid to casualties of a fire disaster, all heads of schools (100\%) in this study had the willingness to extend such help. Again, these findings coincide with the findings by Simatwa and Odera, (2018) who revealed that principals had a strong desire to assist those in immediate danger. Furthermore, majority of teachers $(97.1 \%)$ and students $(69.2 \%)$ in this study expressed affirmative opinions by agreeing that they were willing to administer first aid to casualties of a fire disasters. The findings implied that the heads of schools, teachers and students were ready to provide assistance to casualties of a fire disaster, if secondary schools experienced such adversities.

Pertaining to whether secondary schools received training on first aid, the majority of heads of schools (91.5\%), teachers $(75.9 \%)$ and students $(71.8 \%)$ expressed dissenting opinions by disagreeing on the matter. The findings showed that to a great extent secondary schools did not receive training on first aid; a situation that inhibits the capacity of school community members to provide assistance to victims of a fire disaster, if such incident occurs. These findings coincided with the information obtained from the District Fire Officers who pointed out that although first aid is part and parcel of the training on fire safety they conduct, due to limited time allocated for such training not to interfere with the teaching and other curricular activities at school, training on first aid was rarely done in the training they conducted to students and staff in secondary schools. For instance, a District Fire Officer said that, "first aid is an important component of fire safety training. This part however, has not been given much attention because of limited time allocated for the training we conduct to students and staff in schools."

These findings further implied that students and teachers might have inadequate level of knowledge and skills in administering first aid to casualties of a fire disaster, a situation that might cause even more suffering, injuries or death to those victims of fire disasters, if they occur in schools. These findings are in concurrence with the Ayonga (2016) study findings in Nairobi which revealed that only 1 of the 34 surveyed schools had received training on how to administer first aid to casualties of a fire disasters. Nevertheless, it is imperative that the Fire and Rescue Force conduct training which involves first aid administration as an important component for students and staff to be imparted with knowledge and skills on first aid practices. Such effort might not only help to raise knowledge on first aid administration among students and staff but also help in reducing the risk of victims of fire disasters experiencing more suffering from injuries, emotional infliction or even occurrence of death associated with fire disasters that might occur in secondary schools.

Student prefects are more likely to be immediate first aiders to their fellow students who might be victims, if a fire disaster occurs since they live closely with them. Subsequently, it was vital to determine if student 
prefects were involved in overseeing the well-being of fellow students at school. The findings showed that the majority of heads of schools (97.2\%), teachers (66.1\%) and students (51.2\%) expressed affirmative opinions by agreeing on the matter. The findings suggested that to a great extent student prefects were involved in overseeing the well-being of other students. These findings further implied that if a fire disaster occurs, these prefects could be first aiders in providing assistance needed to victims of a fire disaster after raising a fire alarm; apparently, even before other school personnel like teachers arrive at the scene to help casualties.

When presented with an open ended question, to explain other ways through which secondary schools enhanced their readiness to administer first aid to casualties of a fire disaster, $13(37.1 \%)$ of heads of schools and $52(37.7 \%)$ of teachers and 11(5.2\%) of students indicated that their schools had first aid or resting rooms. While these findings coincide with information gathered through observation where first aid rooms were present in schools, the researcher further noted that more private secondary schools had first aid or resting rooms compared to only a few public secondary schools which had these rooms. Nonetheless, presence of first aid or resting rooms in secondary schools was important in ensuring the practice of administering first aid to casualties of fire disasters is done effectively and efficiently since in some incidents, the victims attended to may require privacy. Furthermore, these rooms were equipped with essential facilities and medical equipment necessary for first aid administration like the resting bed.

\section{Conclusion}

In conclusion, based on the findings, it can be argued that most secondary schools in Kilimanjaro region were to a great extent prepared to administer first aid to casualties of fire disasters because they implemented several practices that built their ability or capacity to not only administer first aid to casualties of fire disasters but also other accidents that could occur at school.

\section{Recommendations}

The study further recommends that heads of schools strictly use funds for procurement of medical facilities they receive as grants from the government to purchase medical facilities in order to enhance safety at school. Such medical facilities include first aid kits. Again, it is recommended that heads of schools should ensure availability of necessary medical facilities in first aid kits by regularly checking them to determine what to add, replace or dispose. This study recommends that Red-Cross society of Tanzania to establish more Red-Cross clubs in secondary schools. While these clubs can be used to instill in students the desire to help those in need, officials or trainers from the Red-Cross could use these clubs to impart more knowledge to students and teachers through training them on how to administer first aid to casualties, especially in a fire disaster incident at school. Similarly, the Fire and Rescue Force should conduct more training to students and staff in secondary school on administration of first aid to casualties of fire disasters, if such menaces occur at school.

\section{References}

1. Amuli, A. J. (2020). Fire Disaster Management Practices in Tanzania's Secondary Schools: A Case of Selected Secondary Schools. University of Dar es Salaam.

2. Ayonga, N. I. (2016). An investigation of fire emergency preparedness in kenyan schools. A case study of public secondary schools in Nairobi. The University of Nairobi.

3. Barton, E. A. (2009). Leadership Strategies for Safe Schools (2nd ed.). Corwin.

4. BBC News. (2018). Uganda School Fire: "Arson Attack” Leaves 10 Dead - BBC News. The BBC News Website. https://www.bbc.com/news/world-africa-46178239

5. Calandrim, L. F., Santos, A. B. dos, Oliveira, L. R. de, Vedovato, C. A., Massaro, L. G., \& Boaventura, A. P. (2017). First aid at school: teacher and staff training. Revista Da Rede de Enfermagem Do Nordeste, 18(3), 292. https://doi.org/10.15253/2175-6783.2017000300002

6. Campbell, R. (2019). Structure Fires in Schools. https://www.nfpa.org/News-and-Research/Dataresearch-and-tools/Building-and-Life-Safety/Structure-fires-in-schools

7. Coppola, D. P. (2015). Introduction to International Disaster Management (3rd. ed.). Elsevier Inc.

8. Felix, J., \& Shani, J. (2020). Ni Simanzi. Mwananchi Newspaper, Pg. 4. 
9. Global Publishers. (2021). Moto Wateketeza Mabweni Shule ya Sangiti. Global Publishers Website. https://globalpublishers.co.tz/moto-wateketeza-mabweni-shule-ya-sangiti/

10. Mutua, E. M. (2016). School-Based Factors Influencing Fire Safety Preparedness In Public Secondary Schools In Lower Yatta Sub-County, Kenya.

11. Nderitu, M. K., \& Muthwii, P. S. M. (2015). A Survey of Disaster Preparedness and Safety Standards in Secondary Schools in Kenya. IOSR Journal of Humanities and Social Sciences (IOSRJHSS), 20(4), 73-80. https://doi.org/https://doi.org/10.9790/0837-20447380

12. Oakley, M., Himmelweit, S. M., Leinster, P., \& Casado, R. (2020). Protection Motivation Theory : A Proposed Theoretical Extension and Moving beyond Rationality — The Case of Flooding. Water, 12(1848).

13. Qureshi, F. M. (2018). First aid facilities in the school settings : Are schools able to manage adequately? Pak J Med Sci., 34(2), 272-276.

14. Raji, I. A., \& Akanbi, A. E. (2019). Emergency risk management factors and effectiveness of public senior secondary schools in the Federal Capital Territory ( FCT). Nigerian Journal of Educational Administration and Planning, 18(1), 14-33.

15. REMS Technical Assistance Center. (2014). Building Blocks to School Safety: A Toolkit for Schools and Districts for Developing High-Quality Emergency Operations Plan. REMS Express, 5(2), 1-5.

https://doi.org/https://rems.ed.gov/docs/BuildingBlocksToSchoolSafety_ToolkitForEOPs.pdf

16. Reveruzzi, B., Buckley, L., \& Sheehan, M. (2020). First aid training in secondary schools: A comparative study and implementation considerations. Journal of Safety Research, 75, 32-40. https://doi.org/10.1016/j.jsr.2020.07.002

17. Ruttoh, J. (2019). Fire Preparedness in Secondary Schools in Eldoret. Journal of Education, Society and Behavioural Science, 31(2), 1-11. https://doi.org/10.9734/JESBS/2019/v31i230149

18. Santhikrishna, C., \& Rekha, P. (2018). First Aid Education for Safety of Students. Journal Of Humanities And Social Science, 23(7), 26-29. https://doi.org/10.9790/0837-2307052629

19. Simatwa, E. M. W., \& Odera, F. Y. (2018). Contribution of Teacher Attitude to Managment of Students Safety in Emergency Incidents in Public Secondary Schools in Kenya - A Case Study of Kisumu County. International Journal of Current Research, 10(07), 71496-71509.

20. Stough, L. M., \& Lee, S. (2018). Seven School-Related Disasters: Lessons for Policymakers and School Personnel. Education Policy Analysis Archives, 26(100), 1-27. https://doi.org/http://dx.doi.org/10.14507/epaa.26.3698

21. Trump, K. S. (2011). Proactive School Security and Emergency Preparedness Planning. Corwin Press. 